\title{
Pelaksanaan Ibadah Shalat Pedagang Pasar di Kelurahan Pariaman Tengah Kota Pariaman
}

\author{
Rani Astuti ${ }^{1}$, Murniyetti ${ }^{2}$ \\ raniastuti744@gmail.com ${ }^{1}$, murniyetti@fis.unp.ac.id² \\ Universitas Negeri Padang 1,2
}

\begin{tabular}{l}
\hline ARTICLE INFO \\
\hline Article history: \\
Received, 05 August 2021 \\
Revised, 24 August 2021 \\
Accepted, 30 November \\
2021
\end{tabular}

\section{Keywords:}

Pedagang Pasar, Nilai

Pendidikan Islam, Ibadah

Shalat

\section{Clonflict of Interest:}

None

\section{Funding:}

None

\begin{abstract}
ABSTRAK
Tujuan penelitian ini adalah untuk mengetahui bagaimana pelaksanaan ibadah shalat pedagang pasar di Kelurahan Pariaman Tengah Kota Pariaman. Jenis penelitian ini menggunakan pendekatan kualitatif yang bersifat deskriptif, sumber data dalam penelitian ini meliputi sumber data premier dan sumber data sekunder, metode yang digunakan dalam penelitian ini adalah observasi, wawancara, dan dokumentasi. Penganalisisan data dengan reduksi data, penyajian data, dan penarikan kesimpulan. Untuk pengabsahan data peneliti menggunakan triangulasi sumber yang berbeda. Hasil dari penelitian ini bahwa pelaksanaan ibadah shalat pedagang pasar di Kelurahan Pariaman Tengah Kota Pariaman dibuktikan dengan hasil observasi dan wawancara kepada pedagang menunjukkan bahwa antara lain: pertama, sudah mengerjakan secara penuh serta mengetahui meninggalkan shalat menghambat rezeki, masih ada yang kadang-kadang mengerjakan shalat, tetapi, mengetahui shalat merupakan kewajiban setiap umat Islam. Serta masih ada yang tidak mengerjakan shalat karena alasan yang tidak jelas.
\end{abstract}

Corresponding Author: Rani Astuti, Department Islamic Education, Faculty of Social Science, Universitas Negeri Padang, Indonesia, Email: raniastuti744@gmail.com Phone: +6281363682975

\section{Pendahuluan}

Sebagai seorang individu yang mempunyai kepercayaan terhadap Islam, maka diperlukan juga pendidikan Islam dalam kehidupan. Dimana pendidikan Islam menjadi alat perubahan pengetahuan dalam bidang keagamaan, sebagai alat perubahan serta penilaian moral untuk pembentukkan sikap, yang memiliki peran dalam mengendalikan tingkah laku seorang individu, dan terciptalah karakter manusia seutuhnya (Choli, 2019). Dari pengertian diatas aspek keagamaan yang dimaksud dalam penelitian ini yaitu tentang ibadah shalat. Dimana ibadah menurut (Abidin, 2020) merupakan semua yang diridhai dan disukai oleh Allah SWT baik itu berupa perbuatan, perkataan, maupun itu suara dalam hati. Selain itu ibadah hanya diperlihatkan kepada Allah SWT, tidak diperlihatkan kepada orang lain(Dimyati, 2014). Ibadah merupakan segala kegiatan yang dilakukan manusia untuk mewujudkan ketaatan dan kepatuhan kepada Allah SWT baik itu berupa kebiasaan yang dianjurkan Allah, juga perbuatan interaksi dengan Allah, sesama manusia, dan alam lingkungan (Apriati, 
2011).Ibadah wajib bagi setiap muslim ialah shalat, karena Allah SWT memberikan kehidupan kepada manusia untuk beribadah kepada-Nya.

Ibadah termasuk semua bentuk cinta dan kerelaan kepada Allah SWT seperti mengerjakan shalat, berpuasa, zakat, naik haji bagi yang mampu, melaksanakan segala perintahnya dan menghindari semua larangannya serta lain sebagainya. Secara individual shalat merupakan salah satu cara pendekatan diri kepada Allah SWT, bukan untuk mengumpulkan harta dan lain sebagainya untuk melakukan kesibukan di dunia (Abror, 2019).

Seperti dalam firman Allah SWT dalam Q.S. Al-Baqarah: 45 dan Q.S. Ibrahim: 40 tentang pentingnya ibadah shalat, sebagai berikut:

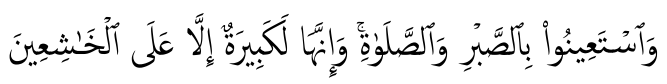

Artinya: Dan minta pertolonganlah dengan kesabaran dan salat. Sesungguhnya salat itu sangat berat kecuali bagi orang yang khusyu' (QS. Al-Baqarah: 45), (Departemen Agama Republik Indonesia, Al-Hikmah Al-Qur'an dan Terjemahannya. 2008: 7).

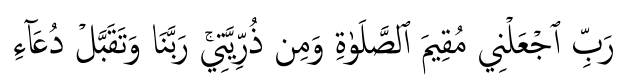

Artinya: Ya Tuhanku, jadikanlah aku dan anak cucuku orang-orang yang tetap mendirikan shalat, ya Tuhan kami, perkenankanlah doaku (QS. Ibrahim: 40), (Departemen Agama Republik Indonesia, Al-Hikmah Al-Qur'an dan Terjemahannya. 2008: 260)

Menurut (As-Sadlan, 2006) dari ayat di atas memberi arti bahwasanya ibadah shalat adalah ibadah yang utama selain peribadatan yang lainnya. Bahwa shalat merupakan tiang agama dan inti ajaran Islam. Ia merupakan penyambung antara seorang hamba yang sadar akan kehambaan-Nya, untuk menasehati dirinya dengan Tuhan-Nya yang memeliharanya dan memelihara alam semesta dengan nikmat dan keutamaannya.

Shalat adalah ciri kecintaan seseorang hamba kepada Rabbnya dan penghargaan atas nikmat-nikmat-Nya, juga merupakan bentuk syukur atas karunia dan kebaikan-Nya. Adapun Raya dan Mulia (2003) dalam (Widi et al., 2017) mengungkapkan hikmah dalam mengerjakan shalat lima waktu: Mendekatkan diri kepada Allah Swt, dengan memperbanyak beribadah kepada Allah Swt merupakan cara mendekatkan diri kepada-Nya. Salah satumya dengan cara mendirikan shalat lima waktu dan tepat waktu. Memperkuat jiwa dan motivasi bahwa shalat dapat menumbuhkan maupun memperkuat jiwa gotong-royong, persaudaraan dan kepekaan serta memperkuat motivasi kita.

Selain itu juga untuk menyatakan Maha Agungnya Allah SWT, memberikan ketenangan jiwa karena shalat maupun ibadah lain dapat menenangkan jiwa bisa mendatangkan ketenangan. Dengan ibadah shalat pengendalian emosi disaat seperti itu akan sangat membantu. Menjaga diri dari kelalaian mengingat Allah, orang yang melaksanakan shalat akan selalu diingatkan agar selalu mengingat Allah Swt sang Maha Besar sehingga kita harus fokus pada tujuan hidup kita yakni di akhirat nanti. Melatih seseorang untuk mencintai keteraturan dan kedisiplinan yang kuat dalam pekerjaan, mengajarkan seseorang untuk memiliki sifat-sifat bijak, ketenangan dan kemuliaan, manajemen waktu yaitu dengan kita selalu mengerjakan shalat tepat waktu, melatih kita dalam memanajemen waktu dalam kehidupan sehari-hari. Membiasakan diri untuk bersikap diri untuk berpikir tentang hal-hal yang positif, melatih untuk membiasakan diri untuk bersikap positif, amanah dan jujur.

Seperti yang telah diuraikan di atas bahwasanya melaksanakan shalat lima waktu sehari semalam merupakan kewajiban setiap muslim. Karena shalat menuntun kita ke jalan yang benar. Di samping itu, manusia merupakan makhluk sosial dan selalu membutuhkan orang lain tanpa lepas dari bantuan. Jadi, tidak ada seorang pun yang dapat mengerjakan semua tugas sendiri tanpa adanya bantuan orang lain. Maka dari itu, sebagai makhluk sosial harus bisa dalam bermasyarakat. Menurut (Kusmanto, 2013) masyarakat merupakan kesatuan hidup manusia yang berhubungan sesuai dengan cara adat-istiadat tertentu yang sifatnya berhubungan, dan terikat oleh suatu rasa pengenalan. 
Rani Astuti dan Murniyetti: Pelaksanaan Ibadah Shalat Pedagang Pasar di Kelurahan...

Pada zaman globalisasi saat sekarang ini, sering kali masyarakat melalaikan ibadahnya demi mencari nafkah atau materi. Namun sebagian masyarakat lainnya tetap melaksanakan ibadah kepada Allah Swt meskipun di tengah-tengah kesibukan yang dijalaninya (Darwindo, 2019). Walaupun mereka melaksanakan ibadah hanya mengikuti syarat dan rukun saja. Oleh sebab itu, ibadah tidak merubah perilaku masyarakat tersebut setelah beribadah seperti bergunjing, iri dan dengki serta riya terhadap yang mereka lakukan. Sedangkan rancangan nilai-nilai ibadah itu sendiri setelah melaksanakannya akan menjadikan manusia-manusia yang adil, jujur dan suka tolong-menolong sesamanya. Sehingga ibadah shalat yang dilakukan bukan semaa-mata melaksanakan kewajiban semata.

Adapun individu yang dimaksud dalam penelitian ini ialah para pedagang, pedagang pasar yang terletak di Kelurahan Pariaman Tengah Kota Pariaman dimana pusat perbelanjaan khas Kota Pariaman merupakan tempat berjualan lebih kurang 200 pedagang yang berjualan di Pasar Pariaman yaitu 100 pedagang kaki lima dan 100 pedagang di toko dimana beraktivitas setiap harinya dari pagi sampai menjelang magrib. Selain itu, berdasarkan observasi yang telah dilakukan bahwa pedagang pasar Pariaman bermayoritas beragama Islam yang tentunya memiliki kewajiban beribadah kepada Allah Swt seperti shalat wajib lima waktu. Shalat adalah rukun Islam kedua dimana pada rukun Islam yang pertama ialah mengucapkan kalimat syahadat maksudnya kalimat tersebut merupakan persaksian karena setelah melafalkan kalimat syahadat maka wajiblah seseorang itu untuk menerapkan rukun Islam salah satunya shalat. Namun pada kenyataannya sebagian pedagang pasar Kota Pariaman masih menganggap melalaikan ibadah merupakan hal yang biasa baginya dan mereka hanya melakukan ketika waktu senggang saja bahkan sengaja meninggalkan shalat. Adapun sebagian mereka melaksanakan shalatnya.

Berdasarkan observasi awal yang telah peneliti laksanakan pada tanggal 6 sampai 9 Februari 2021 di Pasar Kota Pariaman peneliti melihat sendiri dimana ketika waktu shalat telah tiba seperti shalat zuhur dan ashar sebagian pedagang pasar Pariaman lebih memilih melanjutkan dagangnya dan melalaikan shalatnya serta membiarkannya berlalu saja. Selain itu, sebagian melakukan shalatnya. Padahal sebagai orang Islam hendaknya pada saat waktu shalat telah tiba, menghentikan melakukan segala aktivitas dan langsung melaksanakan shalat. Dilihat dari segi shalat di masjid dan mushalla yang telah disediakan di sana tidak begitu ramai dikunjungi oleh pedagang pasar.

\section{Tinjauan Pustaka}

\section{A. Pelaksanaan Ibadah Shalat}

\section{Pengertian Ibadah}

Secara bahasa ibadah (عَادَّة) berasal dari bahasa arab yang memiliki arti patuh, tunduk, merendahkan diri dan hina. Sedangkan pengertian ibadah dari segi istilah banyak dikemukakan para ahli, salah satunya ialah Syahminan Zaini yang mengartikan bahwa ibadah adalah mengerjakan segala apa yang diperintahkan Allah Swt dengan tujuan untuk mendekatkan diri kepada Allah Swt serta hanya semata-mata mencari ridga-Nya (Zaini, 1981)Dalam hal ini pengertian ibadah menurut (Abror, 2019) yaitu semuanya yang mencakup dalam bentuk tuntutan, baik sesuatu yang dapat dimengerti makna nya maupun sesuatu yang tidak dapat dimengerti maknanya seperti thaharah, shalat, yang memiliki hubungan dengan badan seperti ruku', maupun yang memiliki hubungan dengan lidah seperti zikir, bahkan yang memiliki hubungan dengan hati seperti niat. Adapun pengertian ibadah merupakan ibadah yang tidak hanya sebatas berbentuk perilaku, namun berbentuk seperti perkataan yang dilandasi dari hati yang ikhlas sebagai wujud penghambaan seseorang terhadap Tuhannya (Amirah, 2020). Jadi dapat dipahami bahwa ibadah merupakan perbuatan maupun perkataan yang didasari dengan hati sebagai pendekatan diri kepada Allah SWT sebagai wujud penghambaan. 


\section{Ruang Lingkup Ibadah}

Menurut (Abror, 2019) dalam ibadah terdapat ruang lingkup dapat dikelompokkan yaitu Pertama, kewajiban-kewajiban atau rukun-rukun syari'at seperti shalat, puasa, zakat dan haji hal ini dapat dipahami bahwa sesuatu yang tidak dapat ditinggalkan, jika tidak dikerjakan maka berdosa sebaliknya jika dikerjakan maka pahala balasannya. Kedua, yang berkaitan dengan kewajiban diatas segala bentuk perbuatan maupun perintah ibadah lainnya seperti sunnah-sunnah, contohnya membaca Al-Qur'an, zikir do'a dan istighfar. Ketiga, Segala bentuk perbuatan komunikasi (sosial) yang baik terhadap orang tua.

\section{Pengertian Shalat}

Menurut bahasa, shalat yaitu doa, sedangkan menurut istilah merupakan ibadah yang kita laksanakan setiap hari dan terdiri atas gerakan maupun ucapan yang diawali dengan takbiratul ihram dan diakhiri dengan salam yang berdasarkan dengan hukum syariat Islam (Azra et al., 2002). Adapun pengertian shalat ialah suatu proses ibadah yang terdiri dari beberapa ucarapan maupun pergerakan yang diawali dengan takbir dan ditutup dengan ucapan salam yang berlandaskan atas hukum, syarat dan rukun tertentu (Hamid \& Saebeni, 2009). Selain itu, shalat ialah gambaran dari tingkah laku manusia secara lahir dan batin, yang disatukan dengan ucapan (bacaan) berupa permintaan kepada kepada Allah Swt. yang telah ditetapkan, diawali dengan takbiratul dan ditutup dengan salam serta kita beribadah hanya kepada Allah Swt. berdasarkan hukum syariat islam yang telah ditetapkan (Darwindo, 2019). Menurut pendapatpendapat diatas bahwa shalat ialah gerakan mapun ucapan yang diawali dengan takbir dan ditutup dengan salam karena Allah Swt.

\section{Dasar Hukum Shalat}

Shalat terbagi 2 jenis, yaitu wajib dan sunnah (tathawwu), a. Shalat wajib (fardhu) juga terbagi 2 macam yaitu shalat yang memang diharuskan oleh Allah Swt. yaitu shalat lima waktu sehari semalam. Shalat ialah salah satu rukun (pilar) Islam yang memilki kedudukan utama dan sangat strategis dibanding empat rukun Islam lainnya (El-Sutha, 2012).

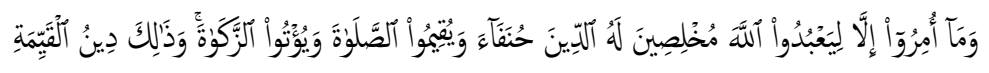

Artinya: Padahal mereka tidak diperintahkan melainkan supaya mereka menyembah Allah dengan mengikhlaskan diri karena-Nya, dengan menjauhi kesesatan, dan (supaya) mereka mendirikan salat dan memberi zakat karena demikian itulah agama yang lurus (Q.S. Al-Bayyinah: 5), (Departemen Agama Republik Indonesia, AlHikmah Al-Qur'an dan Terjemahannya. 2008: 598)

Kedua yaitu shalat yang diwajibkan karena sebab. Seperti seorang hamba yang mewajibkan terhadap dirinya untuk mengerjakan shalat tertentu karena suatu nadzar.

b. Shalat sunnah (tathawwu) juga terbagi 2 macam:

Pertama, shalat sunnah muqayyad, dimana shalat yang sifat dan tata caranya telah ditentukan oleh syarat tertentu. Seperti shalat sunnah tahajud, shalat dhuha, shalat malam, dan shalat tarawih. Kedua, shalat sunnah muthlaq, dimana semua shalat sunnah yang dikerjakan tanpa terikat yang sifat dan tata caranya tidak ditentukan syariat. Seperti seorang hamba yang mengerjakan shalat sunah pada malam dan siang hari berdasarkan keinginannya sendiri.

\section{Waktu-Waktu Shalat}

Di dalam ibadah shalat terdapat waktu-waktu shalat, sebagaimana firman Allah SWT:

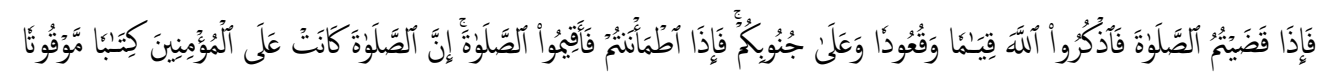

Artinya: Maka apabila kamu telah menyelesaikan shalat(mu), ingatlah Allah di waktu berdiri, di waktu duduk dan di waktu berbaring. Kemudian apabila kamu telah merasa 
Rani Astuti dan Murniyetti: Pelaksanaan Ibadah Shalat Pedagang Pasar di Kelurahan...

aman, maka dirikanlah shalat itu (sebagaimana biasa). Sesungguhnya shalat itu adalah fardhu yang ditentukan waktunya atas orang-orang yang beriman. (Q.S An-Nisa: 103), (Departemen Agama Republik Indonesia, Al-Hikmah Al-Qur'an dan Terjemahannya. 2008: 95)

Sebagaimana juga terdapat dalam hadist Nabi Saw yang berbunyi: Dari Jabir Abd Allah bahwa Nabi Saw didatangi oleh malaikat Jibril a.s dan berkata Nabi: Berdirilah, lalu salat. Maka dia (Nabi) salat zuhur ketika tergelincir matahari. Kemudian Jibril datang pada waktu asar dan berkata: Berdirilah lalu salat. Maka Nabi salat asar ketika bayang-bayang sudah sama panjang dengan benda aslinya. Kemudian dia (Jibril) datang pada waktu magrib dan berkata: Berdirilah lalu salat. Maka Nabi salat magrib ketika terbenamnya matahari. Kemudian dia (Jibril) datang pada waktu Isya dan berkata: Berdirilah, lalu salat. Maka dia salat Isya ketika warna merh di ufuk Barat (syafaq). Kemudian dia (Jibril) datang pada waktu fajar dan berkata: Berdirilah, lalu salat. Maka Nabi salat fajar (subuh) ketika fajar berkilap atau terangnya fajar. (HR. Ahmad, Al-Nasa'I dan Tirmizi)(Abror, 2019).

Dari hadist di atas dapat dijelaskan sebagai berikut (Abror, 2019):

a. Dari terbit fajar kedua (fajar sadiq) sampai terbitnya matahari adalah waktu shalat subuh. Fajar sadiq berarti memancarkan cahaya putih di ufuk timur dimana dalam keadaan melintang dari kiri ke kanan di waktu subuh. Pasangannya adalah fajar kazib yang berarti keadaan cahaya putihnya memanjang dari bawah ke atas langit.

b. Dari mulai tergelincirnya zawal (matahari) sampai munculnya bayang-bayang benda yang sama persis panjangnya dengan benda tersebut merupakan waktu shalat zuhur. Titik menandakan waktu zuhur belum masuk, bila mana bayang-bayang masih persis ditengah atau belum sampai, keadaan ini dapat ditentukan kepada seseorang atau sebuah tiang yang berdiri, Tergelincirnya zawal (matahari) kemiringanya dari pertengahan langit kearah Barat.

c. Titik menandakan waktu asar yaitu sesudah waktu zuhur yang apabila bayangbayanganya melebih suatu panjang benda, sampai terbenamnya matahari. Para ulama mengatakan waktu salat asar menandakan menguningnya cahaya matahari sebelumnya terbenam hukumnya makkruh.

d. Menurut jumhur ulama, waktu salat magrib menandakan mulai terbenamnya matahari, berarti hilangnya bundaran matahari seacara sempurna, sampai hilangya sisa cahaya matahari diwaktu senja atau disebut dengan syafaq. Sedangkan pendapat golongan Syafi'iyah, Hanabilah dan dua orang sahabat Abu Hanafiah (Abu Yusuf dan Muhammad bin Hasan) mengatakan yang berwarna merah berarti syafaq, sedangkan pendapat Abu Hanafiah warna putih-putih yang masih tersisa setelah terbenam matahari yang biasanya masih tetap ada sesudah warna merah.

e. Waktu salat isya yaitu sesudah waktu salat magrib setelah terbit fajar sadiq dengan berarti sejenak sebelum terbit.

Syarat-syarat shalat terbagi 2 jenis yaitu syarat-syarat wajib shalat dan syarat-syarat sah shalat. (Labiz, 2005) mengatakan syarat-syarat wajib shalat diantaranya beragama Islam karena seseorang yang shalatnya ingin diterima, ia harus beragama Islam, dewasa (Sudah baligh) dan berakal, bersih dari najis dan hadats, sudah mendengar seruan atau perintah dakwah Rasulullah, melihat dan mendengar dengan sempurna dan terjaga atau tidak dalam keadaan tidur maupun gila. Sedangkan (Rifa'I, 2016) mengatakan syarat sah shalat terdiri dari bersih dari dua hadas, yaitu hadas kecil dan besar,bersih semua anggota badan, pakaian dan tempat dari najis, menutup aurat, yaitu untuk laki-laki auratnya dari pusar sampai lutut. Adapun wanita semua anggota badan kecuali muka dan telapak tangan.datangnya waktu yang telah ditetapkan untuk setiap shalat, menghadap ke kiblat, mengetahui mana yang fardhu mana yang sunah, dan menghindari hal-hal yang membatalkan shalat.

Menurut (Labiz, 2005) rukun-rukun mengerjakan shalat terdiri dari niat untuk mengerjakannya, berdiri tegak bagi yang mampu. dan shalat bisa dilakukan dengan cara duduk dan berbaring apabila seseorang dalam keadaan sakit, takbiratul ihram pembuka 
semua kegiatan shalat, selalu membaca al-fatihah pada setiap rakaat, rukuk dengan tuma'ninah (diam sebentar), I'tidal diiringi tuma'ninah, sujud dua kali dengan tuma'ninah, duduk antara dua sujud dengan tuma'ninah, duduk tasyahud akhir dengan tuma'ninah, membaca tasyahud akhir, membaca shalawat atas Nabi pada tasyahud akhir, rakaat terakhir disudahi dengan salam, melakukan shalat dengan tertib, dan mengerjakan shalat berurutan sesuai rukun-rukun shalat.

Menurut (El-Sutha, 2012) adapun perkara-perkara yang membatalkan shalat antara lain: membiarkan salah satu rukun shalat tertinggal, makan dan minum didalam shalat, berbicara bukan untuk kemaslahatan shalat, ataupun bukan ucapan yang merupakan rukun ataupun sunnah shalat, tertawa yang menimbulkan suara ataupun terbahak-bahak, perbuatan yang banyak diluar gerakan shalat, karena hal itu bertentangan dengan nilai ibadah, disamping juga hal itu akan menyebabkan hati dan anggota badan menjadi sibuk selain perbuatan shalat, menambah rakaat shalat dengan jumlah rakaat yang sama dengan rakaat shalat yang dikerjakan karena lupa, dan yang terakhir teringat shalat sebelumnya, misalnya seseorang masuk dalam shalat Ashar, dan teringat bahwa dia belum shalat zuhur, maka shalat yang dikerjakannya batal.

Dalam menjalankan suatu ibadah sudah pasti ada tujuan yang dicapai, (Razak, 1993) mengatakan tujuan mengerjakan ibadah shalat diantaranya yaitu supaya manusia menyembah hanya kepada Allah semata, tunduk dan sujud kepada-Nya, manusia selalu ingat kepada Allah yang memberikan hidup dan kehidupan, manusia terhindar dari perbuatan keji mungkar, yang kan mendatangkan kehancuran, mensucikan jiwa manusia agar dapat berkomunikasi dengan Allah, dengan shalat maka akan terbentuk akhlak yang mulia.

Dari sudut religious, shalat ialah menjalin hubungan langsung antara hamba dengan pencipta-nya yang didalamya memiliki makna sebuah kepercayaan kepada Allah dan berserah diri serta mempercayakan segala urusan hanya kepada Allah, diberi keamanan dan ketentraman serta dapat menjadi seorang hamba yang beruntung.

Sebagaimana firman Allah terdapat Al-Ankabut ayat 45:

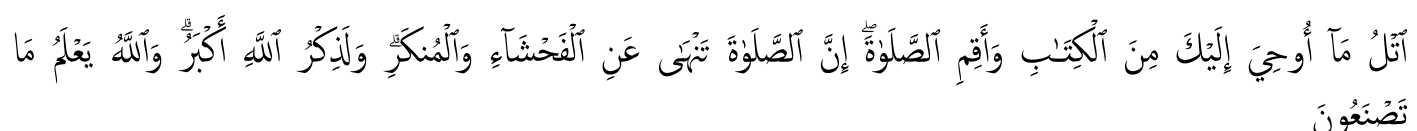

تَصْنَعُونَ

Artinya: Bacalah apa yang telah diwahyukan kepadamu, yaitu Al Kitab (Alquran) dan dirikanlah shalat. Sesungguhnya shalat itu mencegah dari (perbuatan-perbuatan) keji dan mungkar. Dan sesungguhnya mengingat Allah (shalat) adalah lebih besar (keutamaannya dari ibadat-ibadat yang lain). Dan Allah mengetahui apa yang kamu kerjakan (Q.S. Al-Ankabut: 45), (Departemen Agama Republik Indonesia, Al-Hikmah Al-Qur'an dan Terjemahannya. 2008: 391)

Sebagaimana juga terdapat dalam Q.S. Al-Ma'arij ayat 19-22 yang berbunyi:

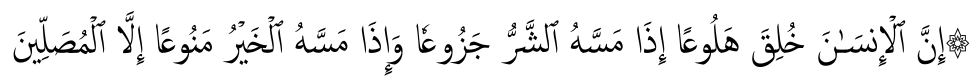

Artinya: Sesungguhnya manusia diciptakan dalam keadaan keluh kesah. Apabila ditimpa kejahatan dia mengeluh dan apabila mendapat keberuntungan dia kikir, kecuali orang-orang yang melakukan salat (Q.S. Al-Ma'arij:19-22), (Departemen Agama Republik Indonesia, AlHikmah Al-Qur'an dan Terjemahannya. 2008: 569)

Jadi dengan dilakukannya shalat maka itu akan mengajarkan seseorang untuk dapat memiliki sikap disiplin dan taat atas berbagai norma yang sudah ditetapkan. Semua ini dapat dilihat dari dari penetapan waktu shalat yang harus dijaga seorang hamba dan melaksanakan shalat sesuai dengan ketentuan yang ada. Jadi, seseorang yang taat pada shalatnya tentu ia akan memahami peraturan, ketentraman, tertib dan mengkonsenrasikan pikiran terhadap hal-hal yang bermanfaat, karena ayat-ayat al-Quran yang dibaca ketika shalat disana terdapat kandungan nilai-nilai tertentu. Shalat merupakan tolak ukur aqidah seorang muslim. Dengan shalat yang baik maka akan menjaga kesatuan dan persatuan hubungan antar sesama. 
Rani Astuti dan Murniyetti: Pelaksanaan Ibadah Shalat Pedagang Pasar di Kelurahan...

Dengan ini maka menumbuhkan interaksi sosial yang baik dan mempunyai pandangan yang sama apabila menghadapi sebuah permasalahan dalam kehidupan (Abror, 2019).

\section{Faktor-Faktor yang Mempengaruhi Meninggalkan Ibadah Shalat}

Faktor internal yaitu datang dari manusia itu sendiri apabila ia melaksanakan sesuatu tanpa adanya dorongan maupun paksaan dari luar. Segala sesuatu itu dilakukan berdasarkan dari dalam manusia itu sendiri. adapun faktor internal ini antra lain: malas yaitu belum adanya kesadaran diri untuk melaksanakan shalat. Sibuk, ini dikarenakan kegiatan pribadi manusia itu sendiri sehingga mereka tidak ada waktu untuk melaksanakan shalat. Faktor eksternal adalah faktor yang berasal dari luar. Yakni dapat mempengaruhi seseorang dalam melaksanakan shalat. seperti lingkungan dan pergaulan

\section{B. Pedagang Pasar}

Pengertian pedagang pasar terbagi dua kata, yaitu kata pedagang dan pasar. Pedagang secara etimologi merupakan orang yang melakukan perniagaan atau berdagang. Menurut (Kensil \& Kansil, 2008) pedagang ialah orang-orang yang melakukan perniagaan sebagai bentuk pekerjaan dalam kehidupanya sehari-hari. Umumnya dilakukan dengan pembelian barang yang akan dijual kembali. Sedangkan menurut (Sutjatmiko, 2014) pedagang merupakan seseorang yang melaksanakan perdagangan, yang diproduksi oleh orang lain, dan diperjualbelikan barang tersebut oleh pedagang lainnya guna mendapat keuntungan.

Adapun pengertian pasar merupakan keadaan yang mempertemukan pembeli dan penjual untuk memperoleh kesepakatan baik itu setiap jenis barang, jasa, atau sumber daya (Karim, 2007). Menurut (Gilarso, 2004) pasar dalam artian kecil ialah tempat para penjual dan pembeli untuk bertemu dalam kegiatan jual beli. Sedangkan dalam arti luas pasar merupakan pertemuan yang terjadi antara penjual dan pembeli untuk melakukan kegiatan jual beli yang tidak memiliki batas waktu maupun ruang tertentu.

Dapat disimpulkan bahwa pedagang pasar adalah seseorang atau orang-orang yang melakukan kegiatan berdagang dimana ada pembeli dan penjual dalam bentuk kegiatan sehari-hari demi memperoleh keuntungan dengan tidak terbatas waktu maupun tempat tertentu.

Terdapat beberapa jenis pedagang menurut (Firdausa, 2012) yakni dapat dikategorikan yaitu: Pertama, pedagang kaki lima yaitu pedagang yang dimana menempati tempat berjualan selain di toko maupun dikios, yaitu dalam los, lias los, dasaran dan playon. Kedua,pedagang toko atau kios merupakan pedagang yang dimana menempati bangunan yang telah disediakan di pasar. Ketiga, pedagang keliling merupakan orang yang melaksanakan penjualan barang dagangan dengan berkeliling memakai kendaraan, kereta, gerobak, sepeda atau sejenisnya. Keempat pedagang asongan ialah orang yang menawarkan dan melakukan penjualan barang dengan cara berjalan kaki.

Selanjutnya (Damsar, 2007) mengatakan bahwa pedagang dibagi atas: pertama pedagang profesional yaitu pedagang yang menjadikan kegiatan dari jual beli yang dilakukannya merupakan sumber utama kelancaran ekonomi keluarganya. Kedua, pedagang semi profesional ialah pedagang yang mengakui aktivitas berjualannya untuk mendapatkan uang, tetapi penghasilan dari hasil jual belinya hanya menjadi sumber tambahan pemasukan ekonomi keluarga saja. Derajat tambahan tersebut berbeda pada setiap manusia dan masyarakat. Ketiga, pedagang subsistensi adalah pedagang yang menjual produk atau barang dari hasil aktivitas atas substensi untuk memenuhi ekonomi rumah tangga. Keempat pedagang semu ialah pedagang yang tidak mengharapkan aktivitas perdagangan sebagai sarana untuk memperoleh uang, ia merupakan melaksanakan aktivitas perdagangan dikarenakan hobi, menginginkan suasana baru serta mengisi waktu luang, dan pedagang jenis ini bisa saja mendapatkan kerugian dalam berdagangnya. 


\section{Metode}

Jenis penelitian yang penulis gunakan adalah penelitian lapangan (field research), dimana penulis terjun ke lapangan dan terlibat secara langsung dengan masyarakat. Penelitian ini merupakan pengumpulan data pada suatu latar alamiah dengan maksud menafsirkan fenomena yang terjadi dimana penulis merupakan sebagai instrumen kunci (Setiawan et al., 2018).

Jadi yang penulis maksud adalah penelitian ini berusaha menggali informasi sesuai gambaran kondisi atau fenomena sosial pada saat melakukan penelitian. Hal ini bertujuan untuk mendapatkan informasi dan data yang valid mengenai pemahaman pedagang pasar terhadap nilai-nilai pendidikan Islam dalam ibadah shalat di Kelurahan Pariaman Tengah Kota Pariaman.

Pada penelittian ini, peneliti memakai teknik pengumpulan data, yaitu: Pertama, observasi, dalam penelitian ini observasi digunakan sebagai alat pengumpul data yang harus di gunakan secara berurutan, dalam artian observasi dan pencatatannya harus dilaksanakan berdasarkan tata cara dan sistematis tertentu sehingga dapat digunakan kembali oleh peneliti lain (Lufri, 2007). Observasi ini digunakan untuk pengamatan secara langsung ke lapangan yang diteliti peneliti untuk memahami peristiwa pedagang-pedagang pasar Kota Pariaman.

Kedua, wawancara merupakan alat pengumpul data yang dipakai apabila peneliti ingin melaksanakan studi pendahuluan untuk mendapatkan permasalahan yang harus diteliti, dan penelitian ini juga digunakan untuk mengetahui hal-hal yang lebih mendalam terkait data yang berasal dari narasumber dengan jumlah narasumber yang lebih sedikit/kecil (Sugiyono, 2011). Penelitian ini yang digunakan yaitu menggunakan teknik wawancara, dengan tujuan agar data yang didapat benar-benar dapat dibuktikan dan dapat dipercaya. Disini pedoman wawancara yang terdiri dari beberapa pertanyaan terkait pelaksanaan ibadah shalat pedagang pasar di Kelurahan Pariaman Tengah Kota Pariaman.

Pengumpulan data dengan metode dokumentasi merupakan suatu cara pengumpulan data yang menghasilkan catatan-catatan penting yang berhubungan dengan masalah yang diteliti, sehingga data yang akan diperoleh menjadi lengkap, sah dan bukan berdasarkan perkiraan. Mengumpulkan data yang sudah tersedia dalam catatan dokumen merupakan metode yang juga sering digunakan oleh peneliti lainnya (Baswori \& Suwandi, 2009).

Ketiga, Dokumentasi. Dalam penelitian dokumentasi ini peneliti gunakan yaitu berupa gambar dan berupa dokumen. Cara ini dipakai untuk memperoleh informasi terkait pelaksanaan ibadah shalat pedagang pasar di Kelurahan Pariaman Tengah Kota Pariaman.

\section{Hasil dan Pembahsan}

\section{Pelaksanaan Ibadah Shalat Pedagang Pasar di Kelurahan Pariaman Tengah Kota Pariaman}

\section{a. Mengerjakan Secara Penuh}

Dalam melaksanakan ibadah shalat tentunya kita harus mengerjakannya tepat waktu. Adapun dalam pelaksanaan ibadah shalat, seseorang harus memahami bahwa meninggalkan shalat juga menghambat rezeki maupun membuat hati seseorang tidak tenang. Allah Swt telah mewajibkan shalat lima waktu sehari semalam. Seorang muslim yang tidak lalai dalam shalatnya, berwudhu dengan sempurna, mengerjakannya tepat pada waktunya dan mendirikannya dengan khusyu' maka Allah Swt berjanji akan memasukkannya kedalam surga.

Dimana dalam pelaksanaan ibadah salah satu pedagang pasar di Kelurahan Pariaman Tengah Kota Pariaman sudah mengerjakannya secara penuh walaupun kondisi pasar yang tidak menentu. Tetapi, pedagang pasar sudah mengamalkan di kehidupan sehari-hari bahwa meninggalkan shalat juga menghambat datangnya rezeki. Berdasarkan teori bab II sebelumnya bahwa mengamalkan merupakan bersungguh- 
Rani Astuti dan Murniyetti: Pelaksanaan Ibadah Shalat Pedagang Pasar di Kelurahan...

sungguh serta mengaplikasikan dalam kehidupan sehari-hari, karena pengetahuan merupakan petunjuk untuk manusia agar selalu berada di jalan Allah Swt.

\section{b. Kadang-Kadang Mengerjakan}

Sedangkan pelaksanaan pedagang pasar di Kelurahan Pariaman Tengah Kota Pariaman yang kadang-kadang mengerjakan shalatnya disebabkan pembeli yang datang bertepatan waktu sehingga shalatnya lupa dikerjakan tetapi pedagang pasar memahami bahwa shalat itu merupakan kewajiban. Dalam hal ini pedagang pasar dikategorikan orang-orang yang melalaikan shalat. Karena ia mengetahui kewajibannya tetapi tidak mau melaksanakannya.

Sedangkan menurut teori lain, shalat wajib yang memiliki nilai keutamaan yang sangat besar, mengharuskan umatnya untuk menjaga waktu-waktunya. Adapun shalat merupakan ibadah yang ringan dan tidak ada kesulitan sedikit pun dalam mengerjakannya, jadi tidak sepatutnya sebagai muslim melalaikan perintah yang sudah diwajibkan ini. Safri rah.a. berkata: "Orang yang meninggalkan shalat subuh akan dipanggil oleh para malaikat, 'Wahai pendosa!'. Orang yang meninggalkan shalat zuhur akan dipanggil, 'Wahai orang yang rugi!'. Orang yang meninggalkan shalat ashar akan dipanggil, 'Wahai ahli maksiat!'. Orang yang meninggalkan shalat maghrib akan dipanggil, 'Hai kafir!'. Dan orang yang meninggalkan shalat isya akan dipanggil 'Wahai orang yang melalaikan Allah!" (Ghaliyatul Mawaa'idz).

\section{c) Tidak Mengerjakan}

Berdasarkan hasil wawancara yang telah penulis lakukan bahwa pedagang pasar di Kelurahan Pariaman Tengah Kota Pariaman yang tidak mengerjakan shalatnya karena disebabkan berhalangan dengan alasan yang tidak jelas disertai pedagang tidak memahami mengenai ibadah shalat hanya mengetahui saja.

Jadi pelaksanaan shalat pedagang pasar di Kelurahan Pariaman Tengah Kota Pariaman masih rendah kesadaran mereka dalam melaksanakan shalat karena masih ada beberapa diantara mereka yang melalaikan ibadah shalat. Hal ini terbukti setelah peneliti melakukan observasi dan wawancara di lokasi tersebut. Meskipun sudah adanya musholla dan masjid disana, tetapi masih saja ada pedagang yang tidak melaksanakan kewajibannya tersebut. Mempunyai kewajiban untuk shalat, kesibukan mencari rezeki tidak sepatutnya menjadi lupa akan siapa yang sesungguhnya Maha pemberi rezeki.

\section{Faktor yang Mempengaruhi Pedagang Pasar Meninggalkan Ibadah Shalat.}

Sebagai seorang muslim yang menjalankan ibadah shalat, seharusnya bisa melaksanakan shalat dengan tepat waktu, apapun pekerjaan yang menghalanginya, seharusnya bisa ditunda terlebih dahulu. Allah Swt berfirman dalam surat Al-Baqarah ayat 45:

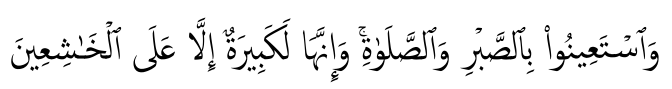

Artinya: Jadikanlah sabar dan shalat sebagai penolongmu. dan Sesungguhnya yang demikian itu sungguh berat, kecuali bagi orang-orang yang khusyu. (Q.S Al-Baqarah: 45). (Departemen Agama Republik Indonesia, Al-Hikmah Al-Qur'an dan Terjemahannya. 2008: 7)

Dalam melaksanakan ibadah shalat terdapat faktor yang mempengaruhi pedagang pasar di Kelurahan Pariaman Tengah Kota Pariaman. Pertama, Kesibukkan. Berdasarkan hasil wawancara penulis lakukan dimana faktor yang mempengaruji pedagang pasar meninggalkan shalat yaitu datangnya pembeli bertepatan waktu shalat. Kedua, Kebiasaan. Berdasarkan hasil wawancara yang penulis lakukan bahwa pedagang menunda-nunda waktu dalam melaksanakan shalat yaitu kebiasaan pedagang Pasar yang suka menunda waktu. Ketiga, Malas. Berdasarkan hasil wawancara penulis lakukan dimana faktor yang mempengaruhi pedagang pasar meninggalkan shalat yaitu malas disebabkan kondisi badan yang tidak sehat dan kelelahan. 
Melihat dari firman Allah SWT di atas, yang harus dilakukan oleh pedagang ialah sungguh-sungguh dalam melaksanakan shalat dan tidak memikirkan barang dagangan mereka, serta tidak boleh malas dengan berbagai alasan dan tidak memperdulikan suasana pasar pada saat melaksanakan ibadah shalat. Sesungguhnya Allah tidak menyukai orangorang yang melalaikan shalat karena kesibukkan di dunia.

\section{Simpulan}

Berdasarkan hasil penelitian mengenai pemahaman pedagang pasar terhadap nilai-nilai pendidikan Islam dalam ibadah shalat dapat penulis simpulkan bahwa pelaksanaan ibadah shalat pedagang pasar di Kelurahan Pariaman Tengah Kota Pariaman dibuktikan dengan hasil observasi dan wawancara kepada pedagang menunjukkan bahwa antara lain: pertama, pedagang pasar di Kelurahan Pariaman Tengah Kota Pariaman sudah mengerjakan secara penuh dan sudah memahami bahwa meninggalkan shalat menghambat rezeki. Kedua, beberapa pedagang pasar di Kelurahan Pariaman Tengah Kota Pariaman masih ada yang kadang-kadang mengerjakan shalat. Akan tetapi, pedagang pasar sudah memahami shalat merupakan kewajiban setiap umat Islam. Ketiga, pedagang pasar di Kelurahan Pariaman Tengah Kota Pariaman masih ada yang tidak mengerjakan shalat karena alasan yang tidak jelas.

Selain itu, pemahaman pedagang pasar terhadap nilai-nilai pendidikan Islam dalam ibadah shalat dibuktikan dengan hasil wawancara dengan pedagang pasar menunjukan bahwa pengetahuan maupun pemahaman terhadap ibadah shalat masih rendah atau secara umumnya kurang paham tentang ibadah shalat. Mereka hanya mengetahui sebatas makna, hukum dan tujuan shalat serta hal-hal yang membatalkan shalat secara dangkal, sedangkan mengenai syarat sah shalat dan rukun dalam shalat mereka belum memahami atau masih kurang memahami.

Adapun faktor pedagang pasar meninggalkan ibadah shalat dapat dilihat dari hasil wawancara dengan pedagang pasar menunjukkan bahwa pedagang pasar meninggalkan ibadah shalat karena berbagai faktor. Antara lain: pertama, kesibukkan dimana disebabkan pembeli yang bertepatan waktu shalat. kedua, kebiasaan pedagang yang suka menundanunda waktu shalat. ketiga, malas pergi ke mesjid maupun ke mushalla disebabkan lokasi pedagang berjualan berjauhan dengan tempat beribadah.

\section{Referensi}

Abidin, Z. (2020). Fiqih Ibadah. Deepublish.

Abror, K. (2019). Fiqih Ibadah. CV Arjasa Pratama Bandar Lampung.

Al Mahfani, M. K. (2007). Buku Pintar Shalat. WahyuMedia.

Amirah, Q. (2020). Efektivitas Sistem Boarding School dalam Meningkatkan Aktivitas Ibadah Peserta Didik di MA Ma'rif NU Kota Blitar. IAIN Kediri.

Anas, Y. (2009). Managemen Pembelajaran dan Instruksi Pendidikan. IRCiSoD.

Antuli, S. A. K. (2017). Pemahaman Masyarakat Tentang Jual Beli Cengkeh Yang Masih Di Pohon (Ijon) Di Kecamatan Passi Barat Kabupaten Bolaang Mongondow. Economic and Business Of Islam, 2, 5.

Apriati, N. (2011). Metode bimbingan islam bagi lanjut usia dalam meningkatkan kualitas ibadah di Rumah Perlindungan Lanjut Usia Jelambar. UIN Syarif Hidayatullah.

Arikunto, S. (2009). Dasar-dasar Evaluasi Pendidikan. PT Bumi Aksara.

As-Sadlan, S. bin G. (2006). Fiqih Shalat Berjamaah. Pustaka as-Sunnah.

Azra, A., Suryana, T., Abdulhaq, I., \& Hafiduddin, D. (2002). Buku Teks Pendidikan Agama Islam (M. Marzuki \& Zulmaizana (eds.)). Departemen Agama RI.

Baswori, \& Suwandi. (2009). Memahami Penelitian Kualitatif. Rineka Cipta.

Choli, I. (2019). Pembentukan Karakter Melalui Pendidikan Islam. Tahdzib Al-Akhlaq: Jurnal Pendidikan Islam, 2 No 2, 35-52.

Darwindo, N. (2019). PEMAHAMAN MASYARAKAT TENTANG IBADAH SHOLAT LIMA WAKTU DI DESA MUARA TIGA KECAMATAN KEDURANG KABUPATEN BENGKULU 
Rani Astuti dan Murniyetti: Pelaksanaan Ibadah Shalat Pedagang Pasar di Kelurahan...

SELATAN. Institut Agama Islam Negeri (IAIN) Bengkulu.

Dimyati, Y. (2014). Upaya Guru Pendidikan Agama Islam Dalam Meningkatkan Ibadah Peserta Didik di Lembaga Pendidikan Ma'arif SMP Islam Durenan Trenggalek. IAIN TULUNGAGUNG.

Eka, S. L. (2018). Pentingnya Pemahaman dalam Prosedur Mengoperasikan Element-Elementelement GMDSS Sebagai Upaya Meningkatkan Keselamatan Berlayar di MT. Minas/P. 35 Milik PT. Pertamina (Persero). Maritim AMNI (UNIMAR AMNI) Semarang.

El-Sutha, S. H. (2012). Buku Panduan Sholat Lengkap. KAWAHmedia.

Fikri, H., Karim, H., \& Muhammad, H. (2021). PELAKSANAAN PENGAMALAN IBADAH SHALAT DI TAMAN PENDIDIKAN AL-QUR'AN MAWADDAH RT 06 KELURAHAN TALANG JAUH KECAMATAN JELUTUNG KOTA JAMBI. UIN Sulthan Thaha Saifuddin Jambi.

Firdausa, R. A. (2012). PENGARUH MODAL AWAL, LAMA USAHA DAN JAM KERJA TERHADAP PENDAPATAN PEDAGANG KIOS DI PASAR BINTORO DEMAK. Diponegoro.

Gilarso, T. (2004). Pengantar Ekonomi Makro. Kanisius.

Hamid, A., \& Saebeni, B. A. (2009). Fiqih Ibadah. Pustaka Setia.

Hidayatul, S. A. (2021). PROBLEMATIKA PELAKSANAAN SHOLAT BERJAMAAH DI DESA KEBAN AGUNG KEDURANG BENGKULU SELATAN. IAIN BENGKULU.

Karim, A. (2007). Ekonomi Mikro Islam. PT Raja Grafindo.

Kensil, \& Kansil, C. (2008). Pokok-pokok Pengetahuan Hukum Dagang Indonesia. Sinar Grafika.

Kusmanto, H. (2013). Peran Badan Permusyawaratan Daerah dalam meningkatkan partisipasi politik masyarakat. Ilmu Pemerintahan Dan Sosial Politik UMA (Journal of Governance and Political Social UMA), 1 No 1, 28-36.

Labiz. (2005). Tuntunan Shalat Lengkap (U. Azizah (ed.)). Sandro Jaya Jakarta.

Limbong, R. I. (2021). STANDAR BACAAN FAQRAUU MAA TAYASSARA MIN AL-QURAAN DALAM SHALAT (Kajian Tafsir Corak Ahkam). UNIVERSITAS ISLAM NEGERI SULTAN SYARIF KASIM RIAU.

Lufri. (2007). Kiat Memahami Metodologi dan Melakukan Penelitian. UNP PRESS PADANG.

Maryam, S. (2018). Shalat Dalam Prespektif Imam Al-Ghazali (Kajian Sufistik). AlL-FIKRAH: Studi Ilmu Pendidikan Dan Keislaman, 1 No 2, 106-113.

Moleong, L. J. (2009). Metodologi Penelitian Kualitatif. PT Remaja RosdaKarya.

Muh, R. D. H. (2020). DINAMIKA PRILAKU MASYARAKAT MUSLIM DALAM HAL IBADAH SHALAT DI DESA LOLOAN KECAMATAN BAYAN KABUPATEN LOMBOK UTARA PASCA BENCANA GEMPA BUMI TAHUN 2018. Muhammadiyah Mataram.

Mursalin. (2018). Nilai-nilai Pendidikan dalam Ibadah Shalat pada Tafsir Al-Azhar Karya Buya Hamka dan Tafsir Al-Maraghi Karya Ahmad Musthafa Al-Maraghi dalam Membentuk Pribadi Muttaqin. Universitas Islam Negeri Maulana Malik Ibrahim Malang.

Pramana, I. N. D., Putra, N. P. S. W., BG, K. W. P., \& Nugraha, K. Y. (2014). Evaluasi Pendidikan. Universitas Pendidikan Ganesha.

Rifa'I, M. (2016). Risalah Tuntunan Shalat Lengkap. Karya Toha Putra Semarang.

Rofiah, N. H. (2018). Penerapan Etika Jual Beli Pedagang Pasar Wage Tulungagung dalam pandangan Islam. Institut Agama Islam Negeri Tulungagung.

Setiawan, Anggito, A., \& Johan. (2018). Metodologi penelitian kualitatif.

Sudjana, N. (2008). Penilaian Hasil Proses Belajar Mengajar. PT Remaja RosdaKarya.

Sugiyono. (2012). Metode Penelitian Kuantitatif Kualitatif dan R\&D. Alfabeta.

Sunaryo Kuswana, W. (2012). Taksonomi Kognitif. PT Remaja RosdaKarya.

Sutjatmiko, E. (2014). Kamus IPS. Aksara Sinergi media.

Widi, E. N. N. W., Saraswati, P., \& Dayakisni, T. (2017). Kedisiplinan Siswa-siswa ditinjau dari Perilaku Shalat Wajib Lima Waktu. Psikologi Islam, 4 No 2, 135-150. 